International Journal of Physical Sciences and Engineering
Available online at http://sciencescholar.us/journal/index.php/ijpse
Vol. 3 No. 3, December 2019, pages: $21 \sim 30$
e-ISSN : 2550-6943, p-ISSN : 2550-6951
https://doi.org/10.29332/ijpse.v3n3.355

\title{
Distribution of Subsurface Anomalies in the Muria Peninsula and Depth Analysis with Euler Deconvolution
}

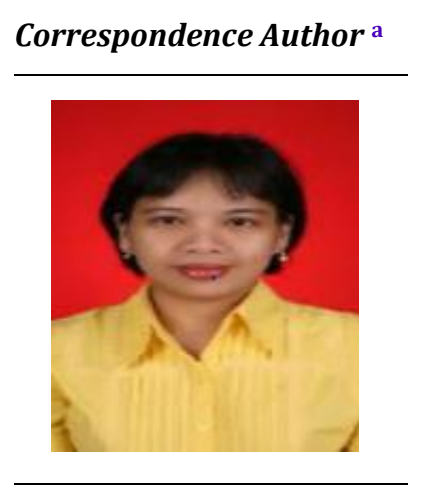

Keywords

\begin{abstract}
Muria Peninsula is one of the regions in Central Java that is uniquely formed. The Muria Peninsula was originally separated from Java and is now connected. To complement the studies that have been done before, subsurface analysis using euler deconvolution method is carried out. Gravity data used is satellite data provided free by BGI. The results of the processing produced a residual anomaly which showed a fault that passed in the middle of the peak of Muria towards Mount Genuk. The anomaly depth of Mt. Muria is $1000 \mathrm{~m}$ to $2000 \mathrm{~m}$, in the peak area of Muria and Genuk $<1000 \mathrm{~m}$, and in the east and west of the study area the anomaly depth is more than $2000 \mathrm{~m}$. Euler deconvolution index 0 illustrates the body boundaries of Mt. Muria and Genuk in the form of dike and steep.
\end{abstract}

distribution;

euler deconvolution;

gravity;

Muria;

subsurface;

e-ISSN: 2550-6943, p-ISSN: 2550-6951 `Copyright 2019. The Author. SS Journals Published by Universidad Técnica de Manabí. This is an open-access article under the CC BY-SA 4.0 license (https://creativecommons.org/licenses/by-sa/4.0/) All rights reserved.

\section{Contents}

Abstract

1. Introduction

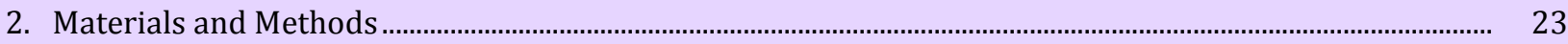

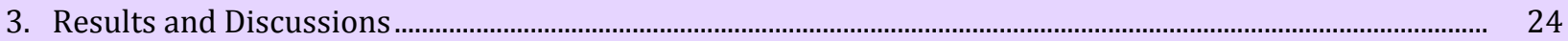

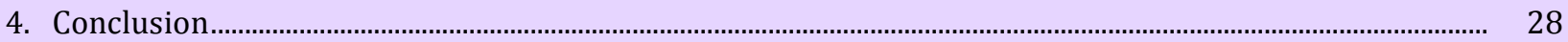

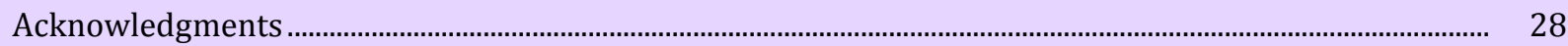

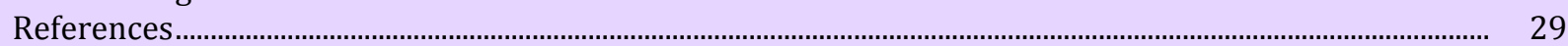

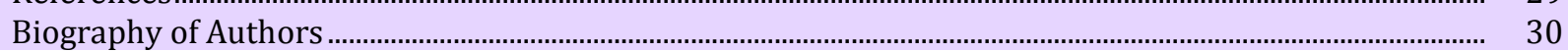

a Universitas Diponegoro, Semarang, Indonesia 


\section{Introduction}

The Muria volcano is one of the mountains in Central Java located on the Muria Peninsula. Administratively, Mt. Muria is located in the northern part of Java Island in Jepara district. The Muria Peninsula region includes Jepara Regency, Kudus Regency, and Pati Regency. On the Muria Peninsula, there are several volcanoes: Mt. Muria, Mt. Genuk, and Mt.Patiayam. Mt. Muria located in the middle of the Muria Peninsula, Mt. Genuk in the north, and Mt. Patiayam in the south. According to Kusumadinata (1979), Mt. Muria was no longer active. It became a recommended place for the location of the NPP (Nuclear Power Plant). Mount Muria provides the smallest risk due to volcanic eruption activity. Mt. Muria eruption can occur again if the tectonic activity occurs on the Muria Peninsula (Bronto \& Mulyaningsih, 2007).

Based on physiographic zones, Muria Volcano is included in the Quaternary Volcano zone. Central Java has six physiographic zones. The physiographic zone of Central Java consists of the Alluvial Plain of North Java, Quaternary Volcano, Bogor Anticlinorium - North Serayu - Kendeng, Central Java Depression, South Serayu Mountains, and Southern Java Mountains (Van Bemmelen, 1949). According to Bronto (2007), the Muria Peninsula was formed as a result of the volcanic activity of Mt. Muria and Mt. Genuk. Deposits of Muria are produced from the volcanic activity of Muria and Genuk which follow the exogenous processes. Exogenous processes consist of weathering, erosion, transportation, and sedimentation that occurs around the volcano and continues up to the coast. Sedimentary lava and alluvium were deposited on the Muria coastal. The rock types of Muria consist of Tufa Muria and Lava Muria rock units.

The geology of the study area as in Figure 1, shows that the Genuk mountain area is composed of Mt. Genuk rocks and is surrounded by sedimentary rocks (Suwarti \& Wikarno, 1992). The landscape of the Muria Peninsula has a river flow pattern centering on Mount Muria. The peak of the Muria is conical with the crater having an oval shape. The oval crater formed is thought to be due to a fault/fracture that cuts through Muria's body. Mount Genuk has a cone peak with a circular crater (Hill et al., 2015).

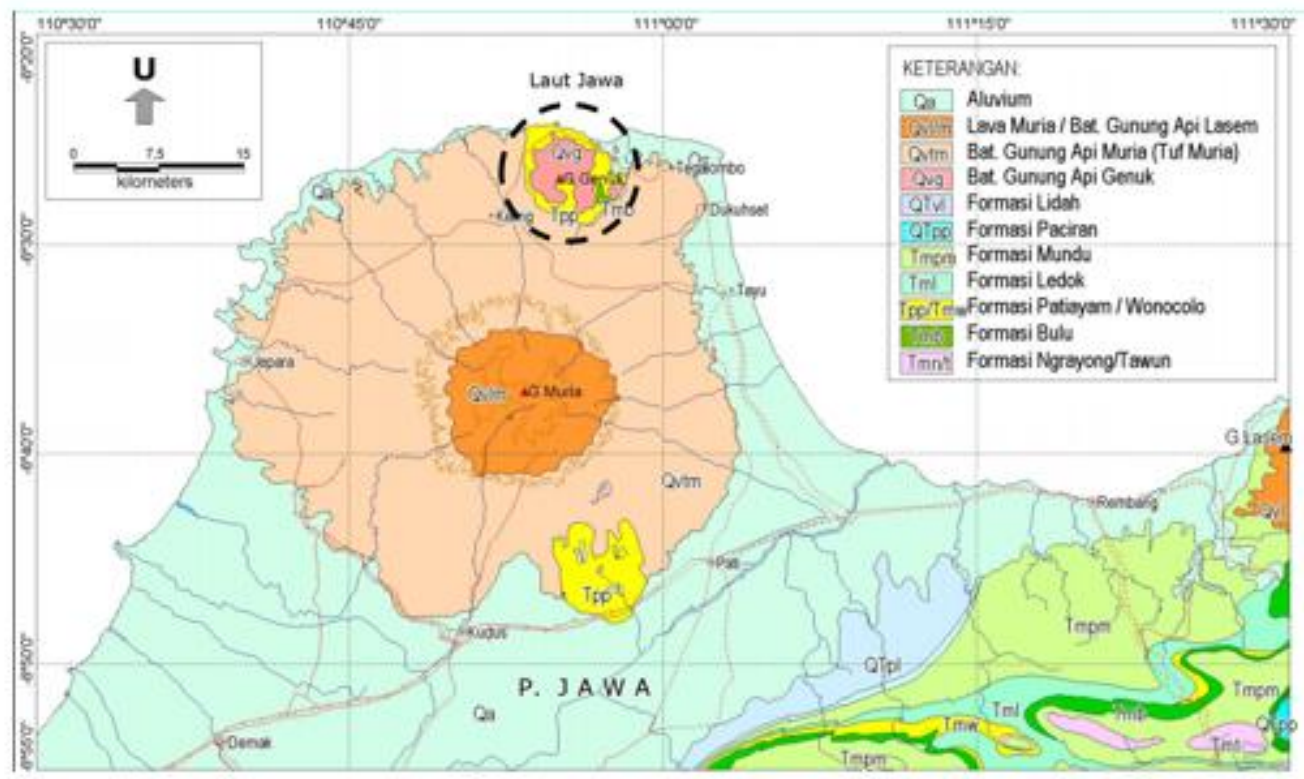

Figure 1. Geological map of Muria Peninsula (Suwarti \& Wikarno, 1992)

Mt. Muria is one of the Maar volcanoes. Maar volcano is a volcano whose basin is filled with water. There are volcanic deposits around the volcano. The diameter of the Maar volcano basin reaches $2 \mathrm{~km}$. Based on satellite imagery, Mt. Muria identify as Maar Volcano. The caldera model is a circular basin. Maar volcano eruption will occur when there is contact between magma and groundwater that fills the basin (Schieferdecker, 1959).

Magma rises to the surface due to a fault. There are two large faults. The faults, which split the summit of Mt. Muria are namely the Tempur fault and the Rahtawu fault. The Tempur Fault extends from the summit of Mt. Muria continuously towards Mt. Genuk. The Tempur fault passed through the village of Tempur. The 
Tempur fault is the oblique fault, the eastern part is the footwall while the western part is the hanging wall. The Rahtawu fault is also an oblique fault. The very steep western fault plane is afoot wall with a triangular facet, while the eastern part is a hanging wall. In the eastern fault plane, outcrops of tuff and breccias are revealed and waterfalls (Astjario \& Kusnida, 2016). Besides the Tempur and Rahwatu faults, there is the Muria-Kebumen fault. The Muria-Kebumen fault was formed due to changes in the subduction pattern on Java Island. The existence of the Muria-Kebumen fault is shown on the interpretation of gravity data (Untung, 1996), Landsat Image alignment (UGM Geology, 1994), and seismic data (Pramono et al., 1990). The presence of the Tempur, Rahtawu, Muria-Kebumen fault and magma reservoir can be identified by gradient analysis, subsurface modeling and other signal analysis. Euler deconvolution is a mathematical method that can be used to calculate the depth of anomaly. This research used Euler deconvolution analysis to calculate the depth of gravity anomaly. Euler deconvolution analysis of gravity will complete the previous analysis, which done with the FHD (first horizontal derivative), SVD (second vertical derivative) and others analysis by using several method (Hilda et al., 2018; Hill et al., 2015, Heni et al., 2011; Usman \& Lugra, 2016; Panjaitan, 2009; Bronto \& Mulyaningsih, 2007).

\section{Materials and Methods}

The gravity method is one of the geophysical exploration methods used to measure variations in the Earth's gravity field. Gravitational field variations occur due to differences in mass density between rocks below the surface. The most basic theory in the gravity method is Newton's law of gravity. Newton's law of gravity explains that the force of attraction between two objects is proportional to the mass of the two objects and inversely proportional to the square distance of the two objects (Sarkowi, 2014; Telford, 1999; Blakely, 1996). Gravity anomaly is the difference between observed gravity with theoretical gravity. Observed gravity is corrected by theoretical gravity. Theoretical gravity called normal gravity. Then normal gravity is corrected by free air correction, Bouguer correction, and terrain correction (Telford, 1999; Blakely, 1996).

There are several methods can be used as an approach to estimate the depth of the anomaly source. The types of depth estimation methods are Peter method, Euler Deconvolution method, Werner Deconvolution, Spectral Analysis, etc. (Handyarso, 2018). Euler deconvolution is an anomaly enhancement method. This method can be applied to geopotential data. The Second Vertical Derivative (SVD) method is commonly used for the delineation of fault structures, while the Euler Deconvolution method is used in estimating the depth of gravity anomaly sources. Initially, the Euler Deconvolution method was used to estimate basement depth in the case of hydrocarbon exploration (Davis \& Li, 2009). In the development of the Euler Deconvolution method used to estimate the depth of the source of anomaly gravity (Handyarso, 2018). The Euler Deconvolution equation can be written as follows (Blakely, 1996):

$$
\left[\begin{array}{lll}
\frac{\partial}{\partial x} g_{i} & \frac{\partial}{\partial y} g_{i} & \frac{\partial}{\partial z} g_{i}
\end{array}\right]\left[\begin{array}{l}
x-x_{0} \\
y-y_{0} \\
z-z_{0}
\end{array}\right]=n \cdot g_{i}
$$

Tabel 1

Indeks of structure type

\begin{tabular}{ll}
\hline $\mathrm{n}$ & Anomaly type \\
\hline 0 & Dyke/sill/step \\
0.5 & step \\
1 & step \\
2 & sphere \\
\hline Source: Yudistira \& Grandis, 1998
\end{tabular}

Source: Yudistira \& Grandis, 1998

Indriana, R. D. (2019). Distribution of subsurface anomalies in the Muria Peninsula and depth analysis with euler deconvolution. International Journal of Physical Sciences and Engineering, 3(3), 21-30. https://doi.org/10.29332/ijpse.v3n3.355 
The research data is secondary data, in the form of Free Air Anomaly satellite data, which downloaded from the website http://bgi.omp.obs-mip.fr on May 20, 2018, at 11:11 WIB. Research area coverage $-6,42^{0}$ to $-7,04^{0}$ $\mathrm{S}$ and $110.57^{\circ}-111.18^{\circ}$. Elevation data used SRTM, downloaded from http://bgi.omp.obs-mip.fr. Processing of FAA (Free Air Anomaly) into a complete Bouguer anomaly using MatLab programming. The mapping of processing results uses Surfer software and Euler deconvolution calculations using Oasis Montaj software.

\section{Results and Discussions}

Figure 2 shows the distribution of the FAA on the Muria Peninsula topographic map. The topography of the Muria Peninsula shows the lowlands and increasing of the topographic towards the top of Muria. Elevation height at $-50 \mathrm{~m}$ to $1612 \mathrm{~m}$. The FAA of the study area is $15 \mathrm{mGal}$ to $140 \mathrm{mGal}$. The FAA of $55 \mathrm{mGal}$ up to 140 mGal located at Mount Muria. The FAA of Mt. Genuk is $60 \mathrm{mGal}$ to $70 \mathrm{mGal}$. The lowland's FAA are15 mGal to $55 \mathrm{mGal}$, and at The Muria peak area are $40 \mathrm{mGal}$ to $50 \mathrm{mGal}$.

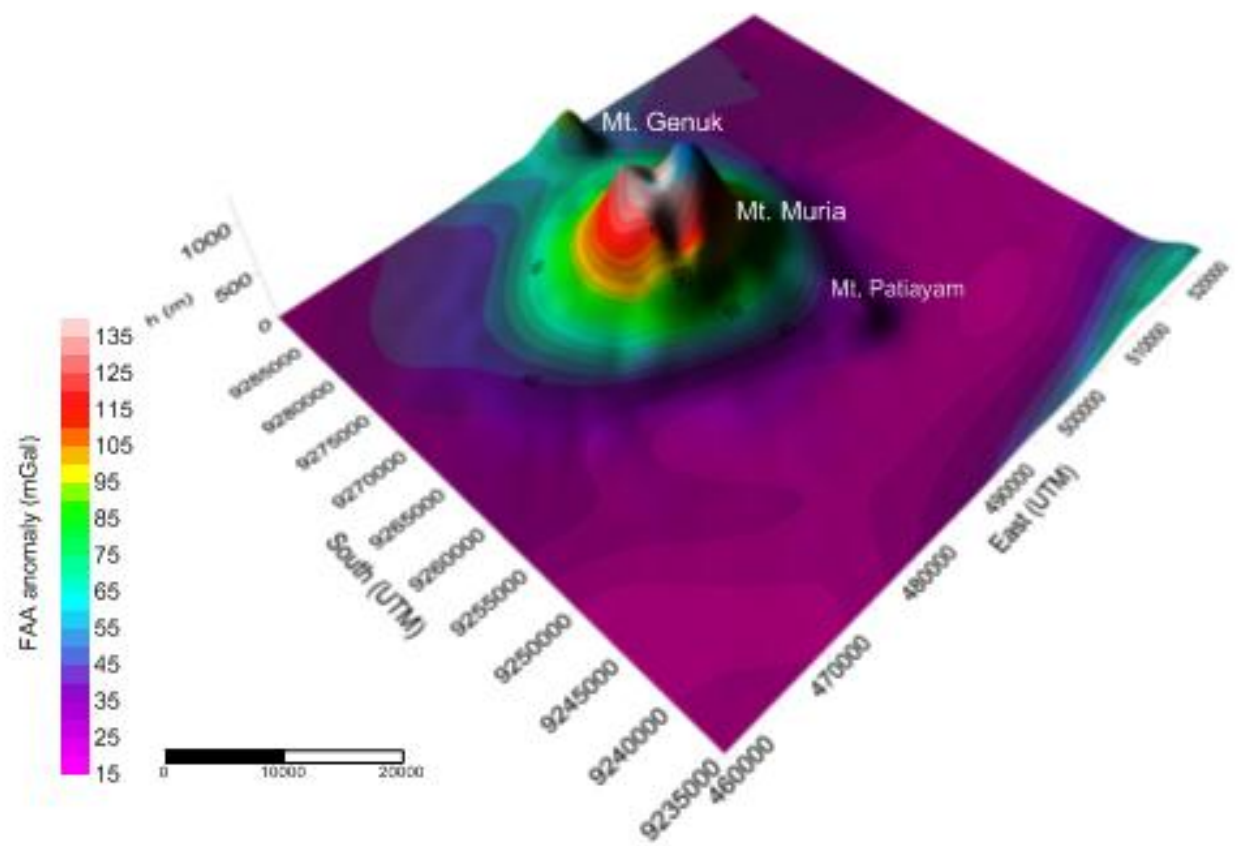

Figure 2. Topographic map overlay FAA contour in the UTM coordinate

The results of FAA processing obtained a Complete Bouguer Anomaly (CBA). The CBA mapped on the topography as in Figure 3. Figure 3 shows the distribution of CBA values is -15 mGal to $65 \mathrm{mGal}$. The CBA 15 $\mathrm{mGal}$ to $30 \mathrm{mGal}$ is located throughout the litoral and lowland areas. The peak area of Muria, CBA value is -15 $\mathrm{mGal}$ to $50 \mathrm{mGal} \mathrm{mGal}$ and Mt.Genuk CBA value is $20 \mathrm{mGal}$. The southern area from Mt. Muria is assumed to be a low-density area. Low-density is the density of sedimentary rock that is alluvial sediment. 


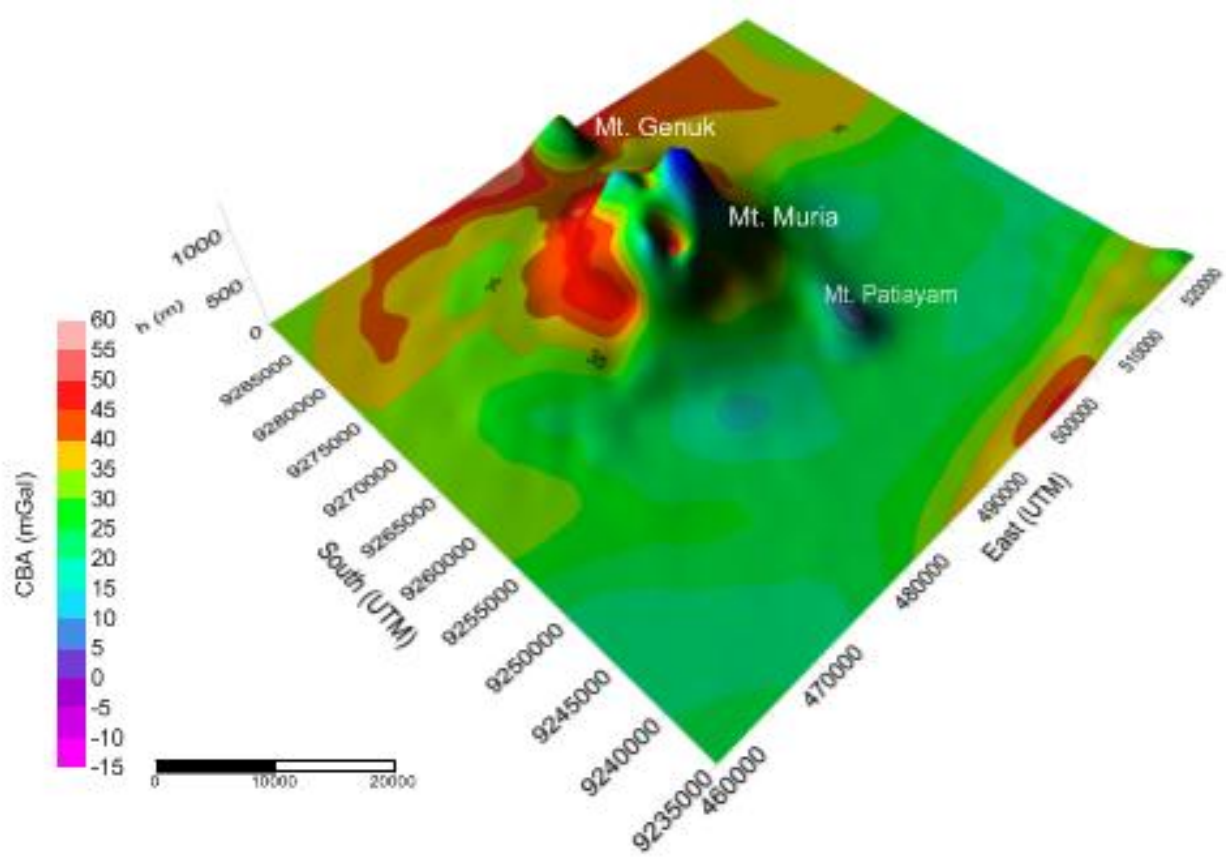

Figure 3. Topographic map overlay CBA contour in the UTM coordinate

CBA on the flat plane mapped in Figure 4, represent CBA at the peak of Muria and Genuk is a low value, while the area around the caldera has higher CBA value. The low value of CBA indicates the caldera, which forms as a basin, contains water or does not contain water. Bronto (2007), explains Muria is one of the maar volcanoes in Indonesia so that the low CBA value can be related to maar type. The depth of the magma reservoir and magma intrusion cause a negative response to the Bouguer anomaly. The high value of CBA, which assumes as a volcanic rock response, spread around the caldera. The volcanic rocks have formed the walls and bodies of the Muria and Genuk volcanoes. Moderate value of CBA, distributed on the slopes of Mt. Muria volcano to the north, which is a response of sedimentary and volcanic sediment that has not been completely compacted.

Indriana, R. D. (2019). Distribution of subsurface anomalies in the Muria Peninsula and depth analysis with euler deconvolution. International Journal of Physical Sciences and Engineering, 3(3), 21-30. 


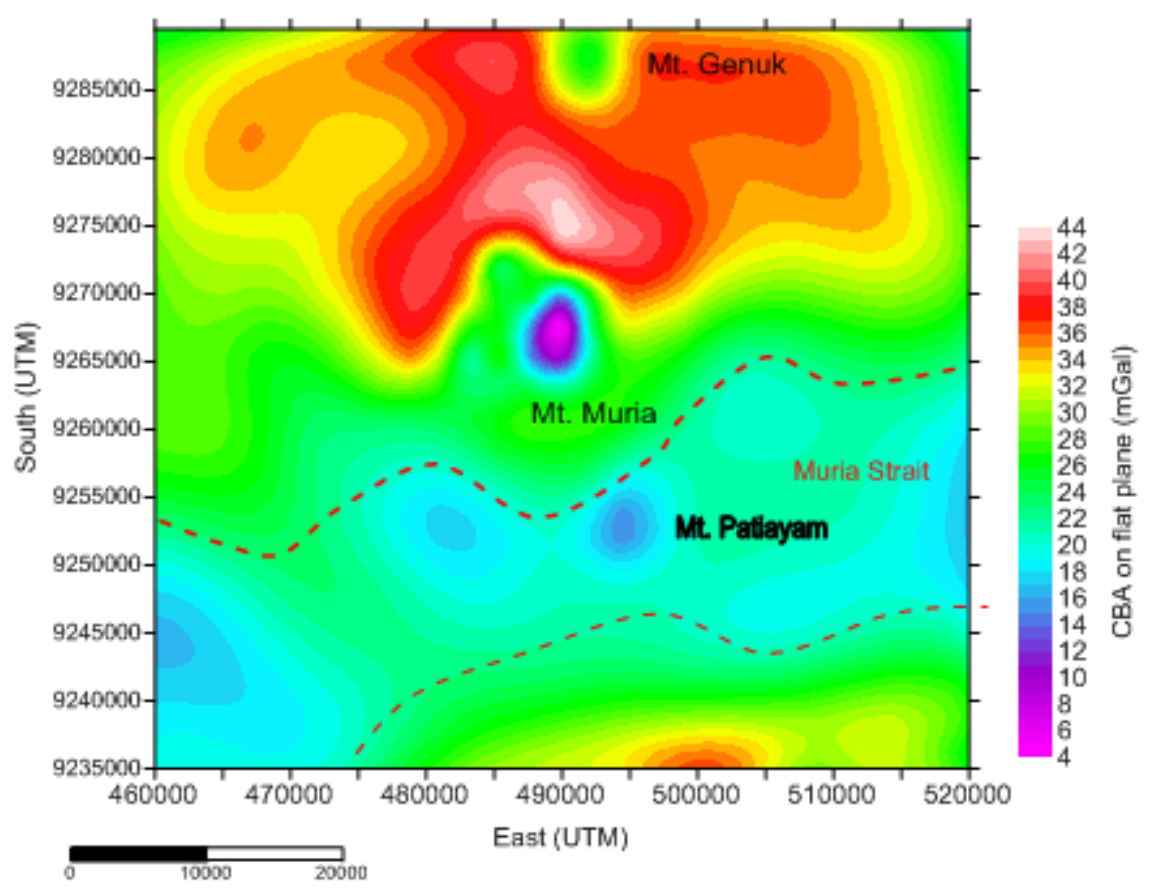

Figure 4. CBA contour on the flat plane

On figure 4, some dense contour patterns plotted at peak area, in the south of the Merapi area and the north of Mt. Genuk. Changes in the pattern of tight anomalies indicated faults or folds. The fold identifies as the basin, namely anticlinorium Pati. The Muria's alluvial deposits are formed due to the deposition process in the basin, coastal and swamp areas. The deposition process in Maria strait occurred in the post interglacial period. In the past, The Muria Peninsula separated from the island of Java. The deposition process of the Pati anticlinorium caused the Muria Peninsula and Java to unite. Anticlinorium formed due to the tectonic process which is part of due to plate subduction (Bronto \& Mulyaningsih, 2007). Pati anticlinorium aged Eocene to Pleistocene, containing sediments with a thickness of up to 5000 meters. Anticlinorium sediments that appear are Ngrayong Formation sediments of Middle Miocene age. Ngrayong sediment is the oldest sediment. Sedimentary rocks are overlain by the Middle Miocene Fur Formation and are overlapped by the Pliocene Age Patiayam Formation. The youngest rocks of the Pleistocene age are Mount Genuk and Mount Muria (Suwarti \& Wikarno, 1992). Pati anticlinorium is a low area as a boundary between the Quaternary Java volcanic lane in the middle of P. Java. Pati anticlinorium direction west to east, longways at Muria Peninsula. Mt. Muria appears on the northern of Pati anticlinorium, which on the slope of the Java Volcanic Arc (Sidarto et al., 1999; Indriana et al., 2018).

Hutubessy (2003), concludes that the regional fault, that controls the Muria Peninsula area is the Tayu fault. Tayu fault directed to southwest- northwest and this fault also controls other small faults. The Tayu Fault controls the occurrence of subsurface cracks that act as a source of magma intrusion that builds the Muria volcano and Genuk volcano (NTT, 2000). In the Muria Peninsula, there are two groups of fault structures, namely: the structure of the Tayu Regional Fault in the northwest-southeast direction and the Bangsri Fault and the Jepara Fault in the southwest-northeast direction. Both groups of fault structures penetrate the bedrock. The Tayu Fault is active again in several Plio-Pleistocene tectonic phases. The last tectonic phase is shown by the formation of G. Genuk which is younger than G. Muria. The ensue of shallow earthquakes in northern Pati, as a result of the activation of smaller local faults, which triggered by regional tectonic processes in southern Java (Usman \& Lugra, 2008; Hutubessy, 2003). The results of the gradient analysis conducted by Anisa et al., (2018), are the first-order horizontal gradient analysis (FHD) show the distribution of the lithological boundaries of the Muria volcano region. Analysis of the second-order horizontal gradient (SHD) was used to obtain a fault direction, but the results of the SHD did not correlate with the location and direction of the fault on the geological map. 
The advanced process of gravity method is the separation of local and regional anomalies. The results of anomalous separation processing are mapped in Figure 5. The distribution of residual anomaly values is mapped in Figure 6 is $-20 \mathrm{mGal}$ to $8 \mathrm{mGal}$. Anomaly residue of $4 \mathrm{mGal} \mathrm{s.d.} 8 \mathrm{mGal}$ located surrounds the Muria peak, from the southwest to the north and continues to the east. The residual anomaly around Mount Genuk is $1 \mathrm{mGal}$ to $4 \mathrm{mGal}$. The anomalies (1 mGal to $6 \mathrm{mGal}$ ) are also mapped in the Kendeng mountain zone. The residual anomaly of Pati anticlinorium is $-4 \mathrm{mGal}$ to $0 \mathrm{mGal}$. The residual anomaly of the peak region of Muria, Genuk, and Patiayam is $-20 \mathrm{mGal}$ to $-6 \mathrm{mGal}$. The lowest residual value is $-20 \mathrm{mGal}$ to $-10 \mathrm{mGal}$, located at Muria summit. In the Muria peak area, several tightly closures are suspected to be related to fractures controlled by the Tayu fault. The close contours around Mount Genuk do not appear, so detection of faults from the top of Muria to Mount Genuk cannot be carried out. The search for the continuity of the Tayu fault, which divides the peak of Muria cannot be detected from the residual anomaly map. The residual anomaly map gives an overview of the distribution of volcanic rocks spread from the peak of Muria to the north. Mount Genuk is surrounded by high rock density, one of which is volcanic rock.

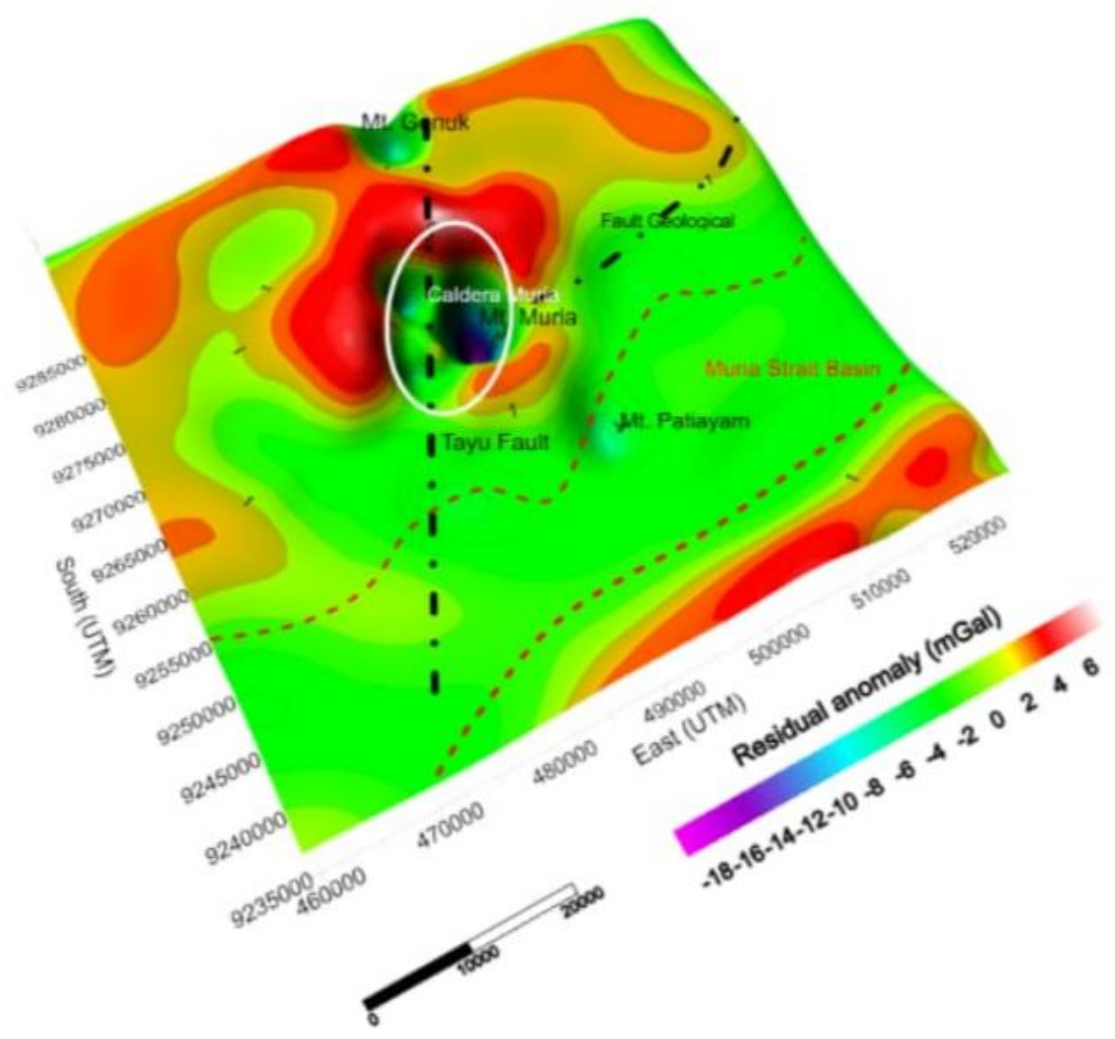

Figure 5. 3D Residual anomaly contour on the flat plane

The residual anomaly map gives an overview of the distribution of masses below the surface. The density of the mass can be related to the residual anomaly value. High anomalies will represent high-density rocks and vice versa. High-density mass is the mass of volcanic rock, while low-density mass is a sedimentary rock. The density distribution obtained does not provide rock depth information. To obtain depth information, further processing is done using mathematical analysis. The density distribution obtained does not provide rock depth information. To obtain depth information, further processing is done using mathematical analysis.

Indriana, R. D. (2019). Distribution of subsurface anomalies in the Muria Peninsula and depth analysis with euler deconvolution. International Journal of Physical Sciences and Engineering, 3(3), 21-30. 


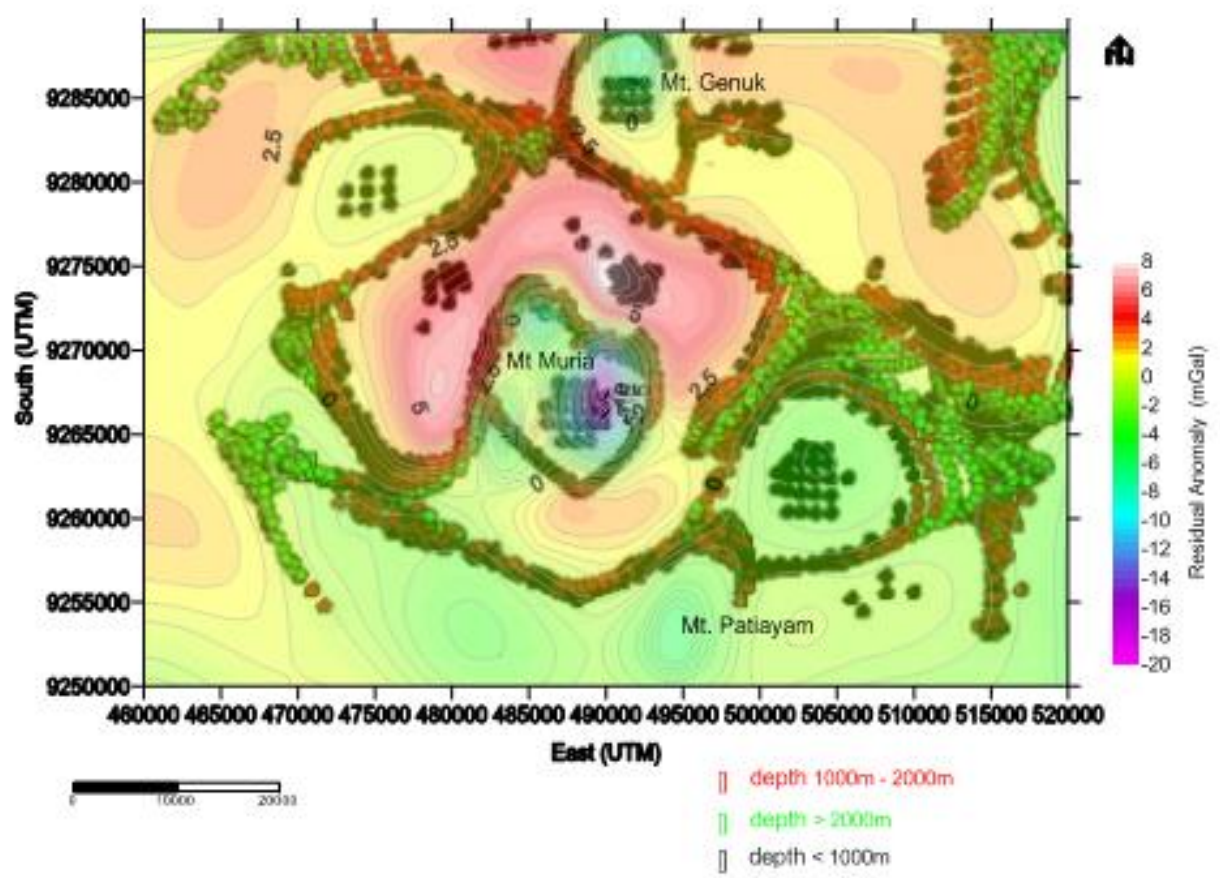

Figure 6. Residual anomaly overlay Euler deconvolution index 0

Figure 6 shows the depth of anomaly in Muria Peninsula. Depth calculation by the Euler method used gravity residual data. In this study, the chosen index number is 0 , which aims to obtain information on the depth of the structure in the Muria Peninsula. The Euler process focuses on Mt. Muria and Mt. Genuk. The Euler deconvolution with index 0, mapped the boundary of rocks in the Muria Peninsula. The body boundaries of Mount Muria and Mount Genuk are clearly mapped by the Euler results, while the patiayam mountain boundaries are not mapped by the Euler. Index 0 is an index that used to obtain the depth of anomalous in the form of the sill, steep, and dike. The Euler result of the study area illustrates the boundaries of steep and dike. The average depth of steep boundaries around Muria and Genuk is $1000 \mathrm{~m}$ to $2000 \mathrm{~m}$. The depth of the Muria and Genuk caldera is more than $1000 \mathrm{~m}$. The Euler mapped the dike respond as a caldera. The Lowest CBA values in the caldera area are related to water, which filled Maar caldera. The east area of the research area, which is the Pati anticlinorium zone (Rembang depression zone), has a depth of dike more than $2000 \mathrm{~m}$. The Anticlinorium zone is bordered by bedrocks with a minimum depth of $1000 \mathrm{~m}$. Deconvolution Euler provides response results for deep and shallow sources. The resulting pattern corresponds to the distribution of local and regional anomalies.

\section{Conclusion}

The research results are a residual anomaly, which showed a fault that passed in the middle of the peak of Muria towards Mount Genuk and the depth of anomaly of Mt. Muria is $1000 \mathrm{~m}$ to $2000 \mathrm{~m}$. In the peak area of Muria and Genuk, the depth of anomaly is $<1000 \mathrm{~m}$ and in the east and west of the study area the dept of anomaly more than $2000 \mathrm{~m}$. Euler deconvolution index 0 illustrates the body boundaries of Mt. Muria and Genuk in the form of the dike and steep.

\section{Acknowledgments}

We acknowledge to Bureau Gravimetrique International (BGI). 
References

Anisa, H. A. N. A., Indriyana, R. D., \& Irham, M. (2018). Aplikasi Metode Gravity Dengan Data Satelit Untuk Identifikasi Struktur Bawah Permukaan (Studi Kasus Semenanjung Muria). Youngster Physics Journal, 7(2), 90-100.

Astjario, P., \& Kusnida, D. (2016). Penafsiran struktur geologi Semenanjung Muria dari data citra satelit. Jurnal Geologi Kelautan, 5(2). http://dx.doi.org/10.32693/jgk.5.2.2007.135

Blakely, R. J. (1996). Potential theory in gravity and magnetic applications. Cambridge university press.

Bronto, S., \& Mulyaningsih, S. (2007). Gunung api maar di Semenanjung Muria. Indonesian Journal on Geoscience, 2(1), 43-54.

Davis, K., \& Li, Y. (2009). Enhancement of depth estimation techniques with amplitude analysis. In SEG Technical Program Expanded Abstracts 2009 (pp. 908-912). Society of Exploration Geophysicists. https://doi.org/10.1190/1.3255897

Handyarso, A., \& Mauluda, A. D. (2018). Penerapan metode dekonvolusi euler untuk estimasi kedalaman sumber anomali. geomatika, 24(1), 21-30. http://dx.doi.org/10.24895/JIG.2018.24-1.726

Heni, M., Hennige, A. M., Peter, A., Siegel-Axel, D., Ordelheide, A. M., Krebs, N., ... \& Staiger, H. (2011). Insulin promotes glycogen storage and cell proliferation in primary human astrocytes. PloS one, 6(6), e21594. https://doi.org/10.1371/journal.pone.0021594

Hill. Gendoet H., Basuki W., Imam H., dan Hadi S, (2015). Kajian Geologi Gunung Api Terhadap Inisiasi Gunung Api Purba Genuk, Jepara, Jawa Tengah

Hutubessy, S. (2003). Struktur Sesar Bawah Permukaan dan Implikasinya Terhadap Pemunculan Kelompok Gunungapi di Semenanjung Muria, Jawa Tengah, Berdasarkan Pendekatan Analisis Gaya Berat. Jurnal Geologi dan Sumberdaya Mineral, 12(133), 37-54.

Indriana, R. D., Brotopuspito, K. S., Setiawan, A., \& Soenantyo, T. A. (2018). Pre and post Mount Merapi eruption of free air anomaly in 2010. International Journal of Physical Sciences and Engineering, 2(3), 7076. https://doi.org/10.29332/ijpse.v2n3.231

Kusumadinata, K., Hadian, R., Hamidi, S., \& Reksowirogo, L. D. (1979). Data dasar gunungapi Indonesia. Direktorat Vulkanologi, Bandung, 820.

NTT, (2000). Volcanological Aspects of Muria Volcanic Complex and Their Hazard Assessment Report, Unpublished report to National Nuclear Energy Agency (BATAN): Feasibility Study of Nuclear Power Plant at Muria Penninsula, Central Java, Indonesia, Volcanology Report National Technical Team Report. Jakarta.

Panjaitan, G. Y. (2009). Akumulasi logam berat Tembaga (Cu) dan Timbal (Pb) pada pohon Avicennia Marina di hutan mangrove.

Pramono, H., Wu, C. C., \& Noble, R. A. (1990). A new oil kitchen and petroleum bearing subbasin in the offshore northwest Java area.

Sarkowi, M. (2014). Eksplorasi Gaya Berat.

Schieferdecker, A. A. G. (1959). Geological nomenclature: Royal Geological and Mining Society of the Netherlands. Noorduyn en Zoon. Gorinchem.

Sidarto, N. S., \& Sanyoto, P. (1999). Sistem sesar Pengontrol Pemunculan Kelompok Gunungapi Muria Hasil Penafsiran Citra Landsat. Jurnal Geologi dan Sumberdaya Mineral, (99).

Suwarti, T., \& Wikarno, S. (1992). Peta Geologi Lembar Kudus, skala 1: 100.000, Jawa. Puslitbang Geologi, Bandung.

Telford, R. J., Lamb, H. F., \& Mohammed, M. U. (1999). Diatom-derived palaeoconductivity estimates for Lake Awassa, Ethiopia: evidence for pulsed inflows of saline groundwater. Journal of Paleolimnology, 21(4), 409422. https://doi.org/10.1023/A:1008092823410

UGM, J. T. G. F. (1994). Geologi Daerah Pegunungan Selatan: Suatu Kontribusi. In Kumpulan Makalah Seminar Geologi dan Geotektonik Pulau Jawa, Sejak Akhir Mesozoik hingga Kuater. Jurusan Teknik Geologi Fakultas Teknik Universitas Gadjah Mada, Yogyakarta (Vol. 23).

Untung, M. (1996). Geoscientific Study Along Jawa-Kalimantan-Sarawak-South-China Sea Transect.

Usman, E., \& Lugra, W. (2016). Tinjauan Geologi Kelautan Perairan Semenanjung Muria terhadap Rencana Tapak Konstruksi Pltn. Jurnal Geologi Kelautan, 6(1). http://dx.doi.org/10.32693/jgk.6.1.2008.145

Van Bemmelen, R. W. (1970). The geology of Indonesia (Vol. 1). Nijhoff.

Yudistira, T., \& Grandis, H. Prosiding himpunan ahli geofisika indonesia.

Indriana, R. D. (2019). Distribution of subsurface anomalies in the Muria Peninsula and depth analysis with euler deconvolution. International Journal of Physical Sciences and Engineering, 3(3), 21-30. https://doi.org/10.29332/ijpse.v3n3.355 


\section{Biography of Authors}

\begin{tabular}{|ll||}
\hline & $\begin{array}{l}\text { Rina dwi Indriana, assistant professor Physics Departemt Diponegoro University., } \\
\text { semarang, Central Java. } \\
\text { Under Graduade Diponegoro University } \\
\text { Master and Doctorah Gadjah Mada University } \\
\text { Subject interest: Geophysics, gravity - volcanology } \\
\text { Email: rina_dei@yahoo.com }\end{array}$ \\
\hline
\end{tabular}

